\title{
Documentário: um outro campo experimental no estudo dos processos de subjetivação
}

\author{
Giovanna De Marco \\ Ana Lorena Oliveira de Andrade \\ Cíntia Sacramento do Espírito Santo \\ Universidade do Estado da Bahia - Juazeiro
}

\begin{abstract}
Resumo
Este artigo traz os problemas colocados para a pesquisa ao propor fazer um mapa audiovisual das configurações subjetivas em processo nas comunidades rurais de Massaroca, Juazeiro, Bahia, finalizando-o em um documentário. Foi feito um estudo bibliográfico e fílmico, particularmente sobre documentário nacional, de modo a adquirir as ferramentas conceituais e instrumentais próprias à linguagem audiovisual. Esse estudo e o trabalho de filmagem, montagem e edição problematizaram o modo de produção do documentário em questões que foram sistematizadas em três pontos: os processos de subjetivação na produção fílmica; o filme enquanto realidade ou ficção; o documentário como uma outra perspectiva metodológica. O documentário no qual a pesquisa estará se apresentando trará em imagens e sons fragmentos dos territórios existenciais das comunidades estudadas, nos quais a tensão existente entre o excesso e a escassez de água é processada, parcialmente, em linguagem; práticas produtivas, econômicas, políticas e éticas; manifestações culturais; religiosidade; afetividade; modos de cognição e percepção, etc.
\end{abstract}

Palavras-chave: processos de subjetivação; comunidades rurais; linguagem audiovisual; realidade-ficção

\begin{abstract}
Documentary: another experimental field in the study of subjective processes. This article brings the problems discussed in the research, which aim at the creation of an audiovisual map of the subjective configurations that are taking place in the rural communities of Massaroca - a district of the city of Juazeiro, Bahia - and produce a documentary with this material. Bibliographic and cinematographic studies mainly about the Brazilian documentaries have been done in order to acquire conceptual and practical tools related to the audiovisual language. This study and the filming works and edition analyzed the documentary production method in three main points: the subjective processes in the cinematographic production; the film as reality or fiction; the documentary as another methodological perspective.
\end{abstract}

Keywords: subjective processes; rural communities; audiovisual language; reality-fiction

A o pesquisar, no período de 1999 a 2003, os processos de subjetivação em curso nas comunidades rurais de Massaroca $^{1}$, Juazeiro, Bahia, por várias vezes se apresentavam situações de intensas afecções compostas por figuras e sons, que sugeriam "cenas cinematográficas", de modo a dar a ver na variação da luz as cores, o contraste entre ambientes internos e externos às casas; no movimento do tempo as mudanças das estações - verde e seca - nas quais se transformam a caatinga, as fontes de água, o vento, as rotinas, etc.; nos deslocamentos pelas comunidades, as diferenças de vegetação, solos, modos de lidar com os animais e a terra; no percurso pelas estradas as cercas recortando as terras e limitando o avanço de pessoas e animais, e as motos, bicicletas e camionetes encurtando os espaços e acelerando os deslocamentos. A singularidade dos diversos modos de existência das comunidades rurais se apresentava de tal modo intensa nessas figuras e sons, estimulando-nos a propor nova pesquisa.

Como trazer essas situações, por meio da linguagem audiovisual, em imagens e sons no movimento do tempo? O problema colocado nos levou a pensar o campo da pesquisa diferentemente do que fizéramos anteriormente, ao privilegiar a escrita ao tecer o mapa das transformações subjetivas das comunidades pesquisadas. Para isso, recorremos à bibliografia sobre cinema e à filmografia, de modo a adquirir as ferramentas 
conceituais e instrumentais próprias à linguagem audiovisual.

Propusemo-nos, então, a fazer um mapa audiovisual das configurações subjetivas em processo nas comunidades rurais de Massaroca, finalizando-o em um documentário. Nesse trabalho os processos de subjetivação são pensados como

não centrados em agentes individuais (no funcionamento de instâncias intrapsíquicas, egóicas, microssociais), nem em agentes grupais. Esses processos são duplamente descentrados. Implicam o funcionamento de máquinas de expressão que podem ser tanto de natureza extrapessoal, extra-individual (sistemas maquínicos, econômicos, sociais, tecnológicos, icônicos, ecológicos, etológicos, de mídia, enfim sistemas que são mais imediatamente antropológicos), quanto de natureza infrahumana, infrapsíquica, infrapessoal (sistemas de percepção, de sensibilidade, de afeto, de desejo, de representação, de imagens, de valor, modos de memorização e de produção idéica, sistemas de inibição e de automatismos, sistemas corporais, orgânicos, biológicos, fisiológicos, etc.). (Guattari, 1986, p. 31)

A subjetividade individual se faz no agenciamento de sistemas de diferentes naturezas, no entrecruzamento de determinações coletivas; ela é, portanto, subtrativa em relação à multiplicidade de agenciamentos maquínicos presentes no mundo ao seu redor. No mapeamento dos processos de subjetivação, realizado na pesquisa anterior, foram trabalhados alguns desses sistemas, nos quais as subjetividades estariam a se determinar. Neste mapeamento audiovisual estaremos priorizando aqueles em que, nos territórios existenciais das comunidades rurais de Massaroca, se apresenta uma tensão polarizada entre o excesso e a escassez de água atravessando os acontecimentos. O excesso de água trazido pelas chuvas, distribuídas irregularmente em um curto período do ano (três a quatro meses), e a sua escassez, decorrente de longo período de estiagem (nove meses, aproximadamente).

Verde e seco remetem a dois períodos temporalmente distintos, porém, um pressupõe o outro em um campo de tensão, campo de forças, que não se dá a um equilíbrio, pois é constitutivo de cada um desses períodos. Seco e verde são modos em que se apresenta essa tensão, havendo nela variações e gradações infinitesimais não capturáveis em definições de estações ou períodos, que não deixam, entretanto, de ter sua existência e de atravessar os processos de subjetivação.

Aqui se coloca outro problema na realização do documentário: como trazer essa tensão em suas variações e gradações, sem confinar os modos de existência em curso nas comunidades a um ou a outro de seus pólos, tal como ocorre nos momentos em que se escasseiam recursos de diferentes ordens, nos riscos trazidos ou pela estiagem prolongada ou pelas fortes chuvas?

O documentário busca trazer em imagens e sons essa tensão processada nos territórios existenciais em que se constituem as comunidades pesquisadas, e na abertura desses para processos irreversíveis de diferenciação necessários e singularizantes.

Os estudos realizados na bibliografia e na filmografia sobre cinema, em especial sobre documentário nacional, e o trabalho de filmagem, montagem e edição nos levaram a problematizar o modo de produção do documentário em algumas questões, que foram sistematizadas em três pontos tal como apresentados a seguir: (1) os processos de subjetivação na produção fílmica; (2) o filme enquanto realidade ou ficção; (3) o documentário como uma outra perspectiva metodológica.

\section{Os processos de subjetivação na produção fílmica}

Alguns textos teóricos, regularmente, trabalham o espectador como um dos pólos de uma relação ativa ou passiva com o filme, fixando-se ora na análise da produção fílmica ora no sujeito, para desenvolver seus estudos sobre como ocorre essa relação. Discutem o sujeito como receptor ou, então, como produtor ativo dos significados das mensagens, ou ainda, os modos de emissão das mensagens em seu poder de determinar, no sujeito, um certo significado. Outros textos entendem o processo de construção da imagem como coexistente à constituição do sujeito/espectador e que ambos mudam ao longo da história do cinema. A nossa perspectiva, neste trabalho, não será a de criticar uma ou outra forma de análise, mas sim a de fazer um mapeamento, no qual possa se dar visibilidade aos processos de subjetivação nelas em curso.

Os estudos até os anos 1980 parecem ter focado um sujeito receptor de imagens, ao qual era dado o papel de apenas receber os significados que se pretendia contidos nas imagens. Entretanto,

a partir do início dos anos 80, os estudos da recepção ou da interpretação de audiências começaram a questionar essa concepção, alegando que, por trás do chamado “receptor” (agora colocado entre aspas) existe um sujeito social dotado de valores, crenças, saberes e informações próprios de sua(s) cultura(s), que interage, de forma ativa, na produção dos significados das mensagens. (Duarte, 2002, p. 65)

Se anteriormente o foco dos estudos voltava-se para as imagens, a partir dos anos 1980 voltou-se para o sujeito. As pesquisas, assim, passaram a supor um sujeito dotado, por exemplo, de valores, crenças, saberes, cultura, que irá interagir com o objeto fílmico na produção dos significados. Alguns estudos chegam a afirmar a contextualização do papel do espectador em termos de sexo, classe, raça, nação, região, entre outros. Acreditam, desse modo, que nem o espectador e nem o objeto fílmico sejam pré-constituídos, fazendo-se na relação (Fernandes et al., 2003). Porém, se há uma relação entre sujeito e objeto, ambos estão sendo pensados como entes, que pré-existem à relação, e que aí chegam dotados de características e modos de funcionamento próprios a um e a outro, podendo, nessa relação, serem alterados.

Contudo, questionar o que ocorre entre as imagens e o espectador, sem tomá-los como pré-existentes, encontrou em nossos estudos elementos que colocavam na invenção do cinematógrafo o momento mesmo de sua constituição, pois

a imagem não é propriamente o que se arruma para a vista, mas o que exige que a vista se arrume para ela. (...) O cinematógrafo inventou o espectador, ou pelo menos um novo tipo de espectador, o que se vê transformado no assunto principal da imagem, o que se vê confrontado com uma imagem que questiona o seu modo de olhar. Esse novo espectador inventado pelo cinema, ali, no instante da invenção, reagiu como se estivesse vendo o mundo pela primeira vez, abrindo os olhos pela primeira vez. 
(Avellar, 1996, p. 218-19)

Assim, um espectador é criado juntamente com o filme e todos os dispositivos técnicos, sociais, culturais, econômicos, publicitários presentes nessa produção. Ou seja, os membros que constituem a relação (espectador e produção fílmica) e a própria relação entre eles se fazem ao mesmo tempo. O sujeito, agora espectador, irá desenvolver um modo de percepção e interação que só podem ser concebidos no instante mesmo do encontro entre ele e o objeto fílmico. Ao assistir a um filme, "o espectador [entra] num fluxo temporal contínuo, que procura seguir e entender...” (Samain, 1998, p. 56). Ainda para o autor citado, o espectador é viajante e navegador em um mundo que se pensa na sua continuidade, no seu fluxo, na sua dinâmica.

Ao se pensar o espectador e o filme produzidos em um encontro, as mudanças que daí advêm na produção fílmica se processarão no espectador, no filme e na relação estabelecida entre eles. Como desdobramento desse processo, é que estariam surgindo diversos tipos de filmes e tendências no cinema, bem como de espectadores, que se buscou e busca estabilizar em uma indústria cinematográfica e em estudos sobre eles. Entretanto, o processo de criação não deixou de se fazer, novos filmes e espectadores vêm surgindo e rompendo com essas tipologias ou idéias de continuidade na história do cinema, apesar da força que elas exercem ao se imporem.

Nessa perspectiva, não é possível pensar um sujeito único, possuidor de uma identidade ou mesmo em atividades de percepção, de imaginação ou de cognição como próprios a ele, porque desse modo estaremos trabalhando com processos préconcebidos. A invenção do cinema exigiu indivíduos com um novo tipo de percepção, imaginação e cognição para que fossem espectadores, os quais não pararam de se transformar ao longo das mudanças na produção cinematográfica.

Os primeiros espectadores, (...) viram o filme com o que poderíamos chamar de bom olhado: num delírio imaginaram cores e tamanhos reais antes que aparecessem as soluções técnicas para (quase) tanto porque de alguma maneira viam que o cinema era não só o esboço que concretamente estava ali - pedaços da realidade objetiva fotografados em movimento - mas o que viriam a ser adiante, uma representação, uma narração em imagem, uma nova linguagem, uma expressão subjetiva. (...) mais tarde, da metade da década de 20 até a metade da década de 50, ao que parece, aconteceu o contrário: o espectador passou a ver a realidade objetiva como se ela tivesse apenas os tons e as dimensões da tela de cinema. (Avellar, 1996, p. 223)

A imagem apresentada nas telas de cinema recebe de seus primeiros espectadores todo um sentido que não estaria presente nos pedaços de realidade fotografados em movimento, mas sim no processo que se instaura a partir de seu encontro com eles. Nesse encontro, como que transportados para dentro de imagens em movimento, espectador e filme se inventam e daí surge uma nova linguagem, uma nova percepção processadas, em um deslocamento no tempo, no qual pessoas e coisas "ocupam um lugar incomensurável ao que têm no espaço” (Deleuze, 1990, p. 53).

Rogério Luz (2002) recorre à noção de experiência ilusória, proposta por Winnicott, para afirmar que a atividade de um espectador ao assistir a um filme não pode ser reduzida apenas ao fantasiar, pois aí se dá também um pensamento inscrito na matéria sensível da imagem e do som. O cinema, ao expressar essa matéria em modos específicos de dar formas ao real, reconfigura-o e metamorfosea-o, tornando-o visível e pensável. O filme se dá como experimento à sensibilidade por meio de elementos estéticos como sensações e intensidades visuais e sonoras antes mesmo de ser objeto de uma atividade crítica e analítica. Pode-se produzir nesse processo uma ruptura com a realidade instituída, o que implicaria em um posicionamento do sujeito, um devir outro, uma nova subjetivação. Desse modo, o espectador torna-se sujeito material de uma experiência estética, na qual o poder de afetar e ser afetado próprio a essa experiência garante ao filme o estatuto de operador de subjetivação.

A produção fílmica se amplia sensivelmente no período de 1920 a 1950, funcionando cada vez mais nos moldes de uma indústria cinematográfica. Grande parte dessa indústria reproduz uma fórmula na qual podem ser identificados os diversos elementos que a compõem, concebendo aí um determinado tipo de espectador. Regularmente, a produção hollywoodiana em sua composição trabalha com personagens psicologicamente definidos - traços, qualidades e modos de proceder -, nos quais é depositada a causa principal da trama e deles surgem as soluções dos problemas ou as ações que possibilitam alcançar ou não as metas. A trama, que envolve a personagem, deverá, ao seu final, chegar a uma conclusão com sua vitória ou seu fracasso (Senra, 1996).

O modelo no qual a indústria cinematográfica se baseia deixa, regularmente, pouco espaço para a participação efetiva do espectador tentando capturá-lo no jogo da trama, cujos elementos estão todos definidos. Espera-se sempre o mesmo espectador, uma identidade constituída em uma relação desigual, na qual o espaço de imaginação, criação, atribuição de significados vai ficando cada vez mais reduzido. Conseqüentemente, esse espectador fixado tende, na maioria das vezes, a considerar boa produção fílmica apenas aquela que se faz no molde dessa composição, podendo rejeitar outras modalidades de filmes, principalmente, aquelas que requerem dele um outro tipo de participação. As produções que não reproduzem esse modelo hollywoodiano são tidas ou como de qualidade inferior, e que um dia poderão igualar-se ao modelo, ou, então, como marginais e, portanto, desqualificadas por esse espectador, que não se dá à experimentação de outras sensações e intensidades visuais e sonoras, senão daquelas que o reconduzem a uma identidade de si que não faz ruptura com o que está instituído.

No Brasil também se produziu uma indústria cinematográfica voltada para um tipo de filme, a chanchada e, posteriormente, a pornochanchada, que previa um tipo de espectador que se aproximava daquele do modelo hollywoodiano. Entretanto, na década de 60 , surgiu na cinematografia nacional outro modo de fazer filme, que não pretendia dirigir-se mais àquele público formado pela grande indústria. Era um filme que buscava uma relação mais intensa com o espectador, supondo sua participação ao lado do realizador. Nessa nova configuração constituiu-se o cinema novo, o cinema marginal e outras formas de experimentar o fazer fílmico, nas quais concebe-se um outro espectador e uma outra relação com a obra. O cinema novo, de sua parte, 
estava articulado com os movimentos que deram origem ao neo-realismo italiano, à nouvelle vague francesa e às teorias dos cineastas russos Dziga Vertov e Sergei Eisenstein. "O cinema marginal, que tem em Ozualdo Candeias uma de suas maiores expressões quebra o modo básico de fruição do espetáculo, transforma o espectador em co-agente, impede a diegese da sociedade contemporânea, ou seja, a distração” (Gardnier, 2007, p.1).

É indiscutível a mudança que houve no cinema brasileiro nos anos seguintes a essas experiências com outras concepções fílmicas, renovação de linguagem e exposição das contradições da sociedade brasileira. Na produção cinematográfica, entretanto, continuarão a se realizar diversas concepções: tanto poderá se reproduzir um modelo de filme que não supõe mudanças nos modos de percepção, imaginação e participação do espectador, mantendo-se a relação espectador/filme dentro do já instituído, como também se buscar um encontro espectador/filme no qual se experimentará um espaço de criação de um novo filme e de novos espectadores. Porém, a criação do novo pelos cineastas não estará livre do risco de transformar-se em uma fórmula por meio da qual eles busquem a reprodução de um resultado anterior.

\section{O filme enquanto realidade ou ficção}

No campo do documentário, o Brasil desenvolveu uma produção reconhecida internacionalmente, que passou por muitas mudanças ao longo do tempo. O estudo das primeiras décadas do cinema revela os documentários de curta metragem e os jornais cinematográficos como sustentáculos da produção e comercialização dos filmes brasileiros. As produções iniciais trabalhavam com os cines-jornais, filmes institucionais, registros de expedições, acontecimentos históricos, festas populares, transformações urbanísticas, entre outros (Catani, 1990).

O documentário era apresentado com uma continuidade narrativa, trabalhava com o método da decupagem² clássica define regras e normas com o intuito de obter uma seqüência visual - e com uma combinação dos planos feita com o objetivo de construir uma seqüência fluente e contínua das imagens, camuflando a sua descontinuidade, processada na montagem, e reconstituindo a relação espaço-temporal. Assim, tentava fazer com que o espectador se achasse diante dos fatos tal como eles teriam ocorrido (Yakhini, 2004). Todo esse processo de produção pretendia manter o espectador nos limites de uma janela de ilusão.

O documentário assim concebido, em contraposição aos filmes de ficção, buscava colocar em suas pré-condições o privilégio do natural, a filmagem de locação, o elenco nãoprofissional e assim reivindicar para si uma suposta essência. Ao recusar a ficção na descoberta de novos caminhos o documentário

conservava e sublimava, no entanto, um ideal de verdades que dependia da própria ficção cinematográfica (...) Era fundamental recusar as ficções preestabelecidas, em favor de uma realidade que o cinema podia apreender ou descobrir. Mas se abandonava a ficção em favor do real, mantendo-se um modelo de verdade que supunha a ficção e dela decorria.(...) Quando se aplicava o ideal ou modelo de verdade ao real, muita coisa mudava, pois a câmera se dirigia a um real preexistente, mas em outro sentido, nada tinha mudado nas condições da narrativa: o objetivo e o subjetivo se definiam de outra maneira, mas continuavam definidas; a narrativa continuava veraz, realmente veraz em vez de ficticiamente-veraz. Só que a veracidade da narrativa não havia deixado de ser uma ficção. (Deleuze, 1990, p. 182)

Os diversos estudos sobre a produção nesse campo têm apontado inúmeras mudanças em relação ao chamado documentário clássico desde a década de 30 no que diz respeito, por exemplo, aos temas, à linguagem, ao documentado, ao espectador, à estética e à montagem. Dziga Vertov já havia radicalizado essa questão ao afirmar que a montagem perpassa todos os momentos da constituição de um filme, desde a escolha do tema, passando pelas filmagens e, finalmente, na mesa de montagem, quando as imagens se articulam tendo em vista a construção e a revelação da realidade (Peixoto, 1998). Vertov não pretendia apenas mostrar, porém, organizar as imagens como um pensamento, fazê-las expressar com uma considerável força a linguagem cinematográfica, universalmente compreendida por todos (Da-Rim, 2004).

Para Deleuze (1990), nos anos 1960 houve uma ruptura no modo do documentário se conceber, situada não entre a ficção e a realidade, mas no novo modo de narrativa que afeta a ambas. Na produção cinematográfica da época identificada como cinema direto (Cassavetes e Shirley Clarke), cinema vivido (Pierre Perrault) e cinema verdade (Jean Rouch), o que vai se opor

à ficção não é o real, não é a verdade que é sempre a dos dominantes ou colonizadores, é a função fabuladora dos pobres, na medida em que dá ao falso a potência que faz deste uma memória, uma lenda, um monstro. (Deleuze,1990, p.183)

A crítica dirigida à ficção não tenciona eliminá-la do documentário, mas liberá-la do modelo de verdade nele presente e buscar a simples função de fabulação. O documentário nesta pesquisa, portanto, não irá buscar a identidade de uma personagem real, mas sim o seu devir quando ela se põe a fabular, tornando-se ela própria um outro.

No Brasil, essa ruptura se expressou no cinema novo, cinema marginal e em outros movimentos, que se processaram a partir dessa década. Surgiu uma nova geração de cineastas documentaristas, que se posicionou de forma crítica diante da realidade brasileira e transformou sua postura em relação ao público. Foram introduzidas a estética e a técnica do cinema verdade ou cinema direto, os quais não buscam eliminar a ficção em favor de uma realidade bruta, mas sim apreender o passado e o futuro coexistentes à imagem presente. Essa, entretanto, não é apenas

inseparável de um antes e de um depois que lhe são próprios, que não se confundem com as imagens precedentes ou subseqüentes, mas, por outro lado, ela própria cai num passado e num futuro, dos quais não é mais que um limite extremo, nunca dado. (Deleuze, 1990, p. 52)

Essas ética e estética estão presentes ainda contemporaneamente no documentário brasileiro, sem, entretanto, constituir um estilo homogêneo. 
O real concebido neste trabalho, diferentemente da visão clássica, não se apóia em definições, determinações, inclusões e exclusões, entre outros. O real, como tratado por Lévy (1996), é constituído por vetores de virtualização e atualização. A atualização, que, nesse caso, aparece como a solução de um problema, não contida no real tal como apresentada, é da ordem da criação, da invenção; enquanto que a virtualização, como movimento inverso, faz a passagem do atual ao virtual, problematizando-o e reinventando-o. Não estamos supondo, assim, um real a ser representado no documentário, mas na sua problematização durante o processo de filmagem em que tal processo deixa de ser entendido como uma captura de imagens em movimento e de sons. Trata-se, no momento da filmagem, de uma composição do real, na qual se atualizam diferentes elementos - temas, personagens, recursos técnicos e estéticos - e as ações neles implicadas. O documentário, como resultado final desse processo, não é pensado em termos de uma maior ou menor veracidade em relação a uma realidade filmada, mas sim é considerado, nessa perspectiva, enquanto uma interferência no real. Desse modo, atualiza-se um real no processo de produção do documentário, que poderá ser problematizado a cada vez, deslocado ou modificado.

No Brasil, a partir de 1980, os níveis de estratificação da produção de documentários atingem

uma espessura de tirar o fôlego, quando então o tema da hibridação dos meios, das estéticas, das formas, dos processos artísticos, técnicos e informacionais não parou mais de lançar desafios ao pensamento, seja na esfera da criação, seja na da reflexão. (Teixeira, 2004, p.10)

Real e ficção não irão aí demarcar duas modalidades divergentes da produção audiovisual, mas um movimento que se processa entre ambos, no qual trocam de papel e se tornam indiscerníveis.

Alguns documentários problematizam a experiência do filmar rompendo com diversos limites, inserem no filme o próprio processo de filmagem, não têm a preocupação de esconder ou camuflar a descontinuidade trazida pelo corte, buscam transmitir ao espectador a idéia de não reprodução da realidade. Essa experiência vem sendo realizada no Brasil, entre outros, por Eduardo Coutinho, ao produzir documentários que não objetivam refletir e nem representar a realidade. Ele trata, "antes, da produção de um acontecimento especificamente fílmico, que não preexiste à filmagem (...) o mundo [para Coutinho] não está pronto para ser filmado, mas em constante transformação" (Lins, 2004, p. 12).

No que diz respeito às modificações que foram sendo introduzidas no cinema é necessário dizer que a presença do realizador e de sua câmera na tela não é algo novo, já havia sido anunciada por Dziga Vertov no filme $O$ homem da câmera de filmar (1929). Porém, o desenvolvimento dessa perspectiva no documentário intensificou-se com o surgimento de novos recursos técnicos (câmeras leves, ágeis, gravador $\mathrm{Nagra}^{3}$ ), permitindo uma grande movimentação no espaço de filmagem e a gravação do som sincrônico ao movimento. Além dessas questões colocadas para a relação estabelecida entre ficção e realidade, outras nos conduzem a pensar o próprio cinema, que “é uma denominação imprecisa, pois restringe-se à forma fílmica (imagens, com estatuto ficcional ou não, exploradas através de uma disposição narrativa com um padrão predeterminado de duração), não tematizando as potencialidades da imagem-câmera que a ultrapassam” (Ramos, 1996, p.144).

Discutir a produção fílmica tematizando as potencialidades da imagem-câmera, como propõe Ramos, é discutir a especificidade da imagem em movimento ao configurar em um intervalo os elementos da realidade naquilo que lhe é essencial, ou seja, o tempo. A imagem-câmera não se confunde, apesar de suas semelhanças, com a imagem formada na superfície da película fotográfica, a qual na seqüência de seus fotogramas faz a recomposição da imagem-câmera. Esse processo, segundo Ramos, se define também em função da qualidade refletora da película, ou seja, das propriedades físico-químicas do material utilizado. Desse modo, a realidade estará submetida a um processo de transformação desde o momento em que é capturada pela câmera em imagens, ao passar pela sua impressão nos fotogramas, até na sua montagem final, quando as imagens são substituídas bruscamente por outras em uma seqüência espaçotemporal, diversa daquela inicialmente filmada.

Os novos recursos (câmeras portáteis, som direto, câmeras digitais, microfone direcional, etc.) não implicam apenas em um aperfeiçoamento técnico, mas sim em mudanças no próprio modo de produzir o documentário, de concebê-lo em uma estética e na composição de suas personagens. O realizador do filme e as personagens filmadas terão sua interação documentada nos acontecimentos, que se movem no tempo mais do que no espaço. Este ponto será desdobrado no próximo tópico.

O novo documentário pede um outro espectador ao trazer nas imagens um tempo que, como já dito anteriormente, não as separa de um antes e um depois, podendo o espectador fazer um deslocamento no tempo. São inúmeros os procedimentos utilizados pelos documentaristas na apresentação das imagens a depender dos objetivos que pretendem alcançar: filmar ou não a si mesmos enquanto interlocutores dos depoimentos, a equipe de produção, a captação de imagem e de som; posição da câmera, uso do microfone direcional, sem fio ou lapela; plano de seqüência ou cortes; perguntas em off ou não; duração do plano; profundidade de campo; escolher a quem entrevistar; definir o que perguntar; prever a intervenção dos participantes no curso da filmagem...

As escolhas, as definições feitas pelo documentarista, na condução da trama, na filmagem e edição não se determinam apenas no domínio do campo profissional, técnico e estético em que ele atua, mas também nas problematizações que aí surgem, colocando em questão o próprio modo de condução da filmagem. Bergson (1992), ao discutir a criação de um romance, assinala o modo pelo qual as personagens passam a interferir no processo de criação, alterando os destinos, anteriormente, propostos pelo autor ou mesmo a trama inicial do romance. Entendemos que, de modo semelhante, na condução da filmagem, as problematizações que surgem interferem tanto nela mesma como naqueles que a realizam.

Nesse sentido, a criação do documentário não tem apenas no realizador a sua origem, ela é deslocada e pensada em um espaço que lhe é exterior - entre o realizador, as personagens e 
todos os profissionais e outros elementos que estão presentes na filmagem -, conferindo uma certa autonomia às personagens e atribuindo a sua criação a todos aqueles envolvidos no processo. Esse processo iniciado antes das filmagens (produção, roteiro, direção, equipe técnica, produção de locação) continua na montagem e edição das imagens e dos sons, quando o realizador “decide” o que excluir, as inserções a serem feitas e a seqüência espaço-temporal a ser montada.

O documentário, assim concebido, compõe/ficciona/cria um "real” no processo de sua realização. E a discussão acerca da veracidade ou não do real é problematizada no cinema pelo documentarista Eduardo Coutinho ao afirmar que:

\section{A verdade da filmagem significa revelar em que situação, em que momento ela se dá - e todo o aleatório que pode acontecer nela. (...) É importantíssima, porque revela a contingência da verdade que você tem (...) revela muito mais a verdade da filma- gem que a filmagem da verdade, porque inclusive a gente não está fazendo ciência, mas cinema. (Lins, 2004, p.144)}

Porém, se diferentemente de Coutinho entendermos a ciência desatrelada de seu propósito de verdade, nela também o que se revela é a contingência da verdade. E, será nessa questão que iremos nos deter no próximo tópico, em que a realização do documentário é pensada como um campo experimental, em uma perspectiva metodológica que o expõe à indeterminação e ao inesperado. O documentário compondo-se das situações flagradas no instante mesmo da filmagem, na singularidade do encontro entre realizador e membros das comunidades rurais da região estudada.

\section{O documentário como uma outra perspectiva metod- ológica}

Buscando não limitar a um significante teórico, que reduzisse os processos de subjetivação à produção de identidades estereotipadas, a perspectiva da pesquisa ao compor um documentário, é apresentar linguagem, práticas produtivas, econômicas, sociais, políticas, éticas; manifestações culturais, de religiosidade, de afetividade; modos de cognição, de percepção; singularizadas nos territórios existenciais em que se constituem as comunidades rurais estudadas.

A linguagem audiovisual favoreceu esta pesquisa no sentido de criar um campo experimental no qual os processos de subjetivação, não centrados em agentes individuais e nem grupais, pudessem ser mapeados no agenciamento de alguns sistemas, sem reduzir a multiplicidade em que se determinam a um significante teórico. Nessa direção aponta a concepção de cinema como

feito de elos semióticos assignificantes, de intensidades, de movimentos, de multiplicidades, que tendem fundamentalmente a escapar ao enquadramento significante e que se rodeiam apenas num segundo momento pela sintagmática fílmica que lhe fixa gêneros, cristaliza sobre eles personagens e estereótipos comportamentais de maneira a homogeneizá-los com os campos semânticos dominantes. (Guattari ,1984, pp. 18-19)

Sem dúvida, tanto a equipe de pesquisa como as personagens, membros das comunidades rurais, não deixam de fazer, no documentário, composições nas quais também se fazem presentes estereótipos que homogeneízam comportamentos com os campos semânticos dominantes. Porém, o problema colocado na realização do documentário é deixar atravessar o campo experimental pelos acontecimentos, por aquilo que não se dá a conhecer de imediato, que escapa aos limites da significação. Deleuze e Guattari (1992, p. 213) pensam esse atravessamento se dando através de perceptos, não como percepções, pois “são independentes do estado daqueles que os experimentam”, e de afectos, não como sentimentos, pois "transbordam a força daqueles que são atravessados por eles”. Os atravessamentos expõem o campo experimental à indeterminação e ao inesperado dos acontecimentos, tensionando-o, provocando fissuras.

O campo experimental assim concebido retirou os membros da equipe realizadora do centro de determinação da pesquisa, o processo não se definiu nos significantes teóricos, mas sim nos acontecimentos. Ou seja, a equipe ou parte dela era forçada a redefinir seus procedimentos no próprio processo e a se reposicionar em relação às personagens constituídas no documentário, a fazer os conceitos operarem nos diversos momentos do trabalho (filmagem, edição), a repensar a pesquisa em suas discussões ao produzir relatórios, artigo e trabalhos para apresentar em eventos de caráter científico. Posteriormente, foi na edição e montagem que a experimentação foi se processando. Dúvidas e incertezas, freqüentemente presentes, não constituíam obstáculos ou impossibilidades para manter a experimentalidade na pesquisa, mas sim como anunciadoras de problemas a serem delimitados e formulados, para daí buscar as soluções.

A equipe da pesquisa, ao estabelecer uma temática e se colocar em contato com pessoas, modos de existência, teve nesse processo a matéria subjetivada, na qual se definiram as alternativas em relação à situação a ser filmada (posicionamento de câmera, utilização da câmera na mão ou no tripé, uso de entrevistas ou narração, presença ou não do realizador em quadro, inserção musical). No espaço do encontro da equipe com as situações de vida flagradas, o documentário foi se compondo. A coordenadora da pesquisa sem um roteiro pré-estabelecido fez contato prévio com as pessoas e os locais de filmagem e não definiu as situações e as falas, que iriam se desenvolver no decorrer dos acontecimentos na filmagem. Isso não quer dizer que não houvesse um projeto de filmagem, temáticas a serem tratadas e questões a orientar o trabalho, advindas da pesquisa anteriormente realizada. Esse processo exigiu um envolvimento e um deter-se junto às pessoas e nos locais de filmagem.

Nos anos 1950 e 1960, segundo Bernardet (2003), o documentário no Brasil introduziu o nordestino, o operário, o favelado, pescador, cerimônias religiosas, entre outros, como personagens e empregava, regularmente, a entrevista como estratégia para dar a palavra ao outro que não teria um lugar para falar. Era o realizador quem fazia a entrevista e definia o conteúdo das perguntas. Ele esperava, desse modo, facilitar uma aproximação sua com as pessoas, criar uma intimidade para que elas se expressassem. O documentário tinha o seu foco central na relação entrevistador e entrevistado, mesmo quando o entrevistador não se fazia presente na tela ou quando as perguntas eram ocultadas. $\mathrm{O}$ autor critica o uso da entrevista no documentário, por duvidar desse recurso como meio de 
aproximação entre o entrevistador e o entrevistado. Afirma ainda que há uma contemplação em relação ao outro, revelada em atitudes cerimoniosas, fazendo aparecer um sujeito que não pode se colocar como sujeito. A concentração na entrevista enfraquece outras formas de aproximação do outro, empobrece a observação e elimina uma série de possibilidades narrativas e dramáticas. Além disso, ao centralizar o documentário na relação entrevistador e entrevistado são desprezadas as relações entre as pessoas filmadas.

A crítica de Bernardet ao uso da entrevista no período analisado dá visibilidade a concepções também encontradas com freqüência em muitas pesquisas científicas realizadas com as populações mencionadas. Como não pretendíamos reproduzir essas concepções ou buscar a identidade das comunidades rurais pesquisadas, problematizamos o modo de concepção da entrevista, sem, entretanto, descartá-la. A entrevista pode ou não ser um instrumento de aproximação, mas não é a sua garantia. Além da entrevista, nesta pesquisa foi preciso um deixar-se ficar, em determinados momentos do trabalho, os quais se transformavam em uma quase 'conversa', na qual uma resposta era alongada ou conduzia para pontos não previstos. Em outros, a personagem passava a contar “causos”, lendas, piadas, fazendose um tempo que dava outra condução à filmagem. Era nesses momentos, em que a pesquisa atravessada pelo indeterminado no acontecimento, que a personagem começava a fabular e não nos interrogávamos sobre a veracidade ou não daquilo que era apresentado, deixando que desse curso ao trabalho. Pois, como afirmou Deleuze (1990), a personagem não podia ser separada de um antes e de um depois, que nela se reuniam na passagem de um estado a outro. Entendemos que, ao fabular, ela se afirmava ainda mais como real e não como fictícia, pois aí uma lenda, uma família ou uma comunidade se inventava. A própria personagem, ao fabular, tornava-se outra. Os membros da equipe de pesquisa, por seu lado, ao tomar a personagem real como intercessor e substituir suas pré-concepções/ficções pelas fabulações dela, também se outrava.

Xavier (2003), de sua parte, assinala na entrevista uma relação de poder assimétrica, estabelecida entre aquele que faz o filme e as pessoas que contam suas histórias. Nessa relação, o documentarista fixa uma temática e através de perguntas busca abordá-la, ficando, assim, o poder nele concentrado. $\mathrm{O}$ documentarista, por meio do recurso da entrevista, busca a alteridade no personagem, mas o que se revela, regularmente, é um sujeito pré-concebido, suposto na temática e nas perguntas formuladas. Desse modo, o documentarista não se confronta com aquilo que possa deslocá-lo do já sabido e arremessálo em situações desconhecidas, nas quais ele mesmo deverá subjetivar-se, despojando-se de uma imagem identitária que, segundo Rolnik (1998), reduz o reconhecimento de "si” a um contorno, a uma imagem que se pretende igual a ela mesma, e impede um efetivo encontro com o outro. Para Xavier (2003, p. 2) "o falar é uma forma de agir, mas o que define personagens dentro de uma tradição é aquilo que as coloca em conflito de vontades, interesses, idéias e situações que se decidem no plano da ação".

Foi nesse plano que as filmagens foram atravessadas por um tempo, no qual as personagens falavam de si próprias em fabulações que, provavelmente, não existiriam fora do acontecimento filmagem. Na medida em que adotara uma perspectiva experimental, a equipe tinha as personagens como intercessores na filmagem e concebia essas situações como problematizadoras. Estava claro também que o poder enquanto força, partindo de Foucault (1982), não estaria fixo em um dos termos da relação, tal como discutido por Xavier, mas sim circulando entre os envolvidos exercendo-se de modo assimétrico. As personagens propunham temáticas, cenários ou um melhor modo de se fazer uma tomada. Algumas delas assumiam uma postura crítica em relação ao modo como fazíamos uma pergunta e configuravam a resposta em seus próprios termos. Outras se apresentavam em situações imprevistas, que arremessavam toda a equipe no indeterminado e ao enfrentá-las, não podendo reduzir o reconhecimento de si e do outro em uma representação, configuravam-se novos processos de subjetivação que se expressavam nos efeitos daí decorrentes. Porém, enquanto tomada nessas situações, a equipe nem sempre tinha clareza acerca dos resultados. Só posteriormente, quando se reunia para discutir os efeitos por eles produzidos, podia pensar essas experiências de forma mais sistemática em outras atividades (diário de campo, artigo, fórum científico, montagem e edição do audiovisual, etc.).

$\mathrm{Na}$ atividade de filmagem propriamente dita uma das implicações da perspectiva experimental era ter atenção às situações não previstas, aos gestos, às expressões faciais ou corporais, às ações, nas quais pudéssemos capturar aquilo que buscava manifestar-se e pedia de nossa parte uma sensibilidade para tal. Essa perspectiva exigia um estar presente às filmagens e uma sintonia entre a pesquisadora/diretora/entrevistadora (essas diversas atividades ficavam concentradas nesse momento) e o cinegrafista, sintonia essa nem sempre alcançada. Na captura das imagens era necessária uma comunicação entre ambos para que o cinegrafista soubesse o tempo que deveria deter-se em uma determinada paisagem, em um gesto, em um olhar; mudar o foco da câmera quando a situação o exigisse; dar maior profundidade de campo, por exemplo.

Filmamos apenas com uma câmara digital (Sony DSRPD170), o que nos impediu de capturar outras imagens simultaneamente, as quais nos possibilitariam obter outros ângulos e aspectos da situação focada. A gravação dos sons foi feita através de um microfone acoplado à câmera, pois não tínhamos o unidirecional, melhor indicado para o nosso trabalho. Mesmo utilizando o rebatedor, o ruído do vento está muito presente nas tomadas externas e comprometeu a qualidade de parte do material, assim como outros ruídos que interferiram no momento da gravação. As filmagens foram programadas para ocorrerem em dois períodos - verde e seco - do ano de 2005 nas comunidades rurais.

No processo de edição e montagem procuramos as respostas aos problemas colocados pela pesquisa. Como trazer nas imagens e sons a singularidade dos diversos modos de existência das comunidades rurais? Como trazer essa diferença? Como relacionar as imagens em uma temporalidade sem submetê-las simplesmente a uma linearidade cronológica?

Um procedimento utilizado durante as filmagens e também na montagem e edição foi não trabalharmos com um 
roteiro prévio. Os problemas colocados por nossa perspectiva experimental nos conduziam por caminhos que se definiam no processo mesmo de filmagem. Nós não determinávamos sozinhos os rumos a serem tomados, em algumas circunstâncias nos vimos sendo dirigidos pelo entrevistado/personagem, que sugeria o modo e local onde poderia ser feita a filmagem, que trazia “causos”, histórias, temáticas ou situações, que interferiam no curso da filmagem. Em algumas comunidades nos deparamos com situações que compunham um determinado cenário, tivemos que enfrentá-las como se apresentaram sem ter muita idéia, no início, para onde poderiam nos levar. Esse enfrentamento situava a pesquisa na experimentação tal como proposta, constituía desafios aos quais dávamos respostas forjadas no momento mesmo da filmagem. É claro que nem sempre esse processo trouxe resultados interessantes, mas forçou os envolvidos a se deslocarem de suas concepções, a abrirem sua sensibilidade para o outro que tinham diante de si.

No processo de montagem e edição fizemos uma préseleção nas quarenta horas gravadas e decupadas das imagens que apresentavam melhor qualidade e atendiam ao objetivo da pesquisa. Posteriormente, foi feita uma nova seleção das imagens produzidas em cada comunidade rural e, em seguida, uma montagem que tomou como referência as relações sugeridas pelas próprias imagens. Repetíamos esse procedimento com as imagens feitas em cada comunidade. Na seqüência das imagens não se trabalhou o tempo nos acontecimentos numa perspectiva cronológica, o tempo não resultou do encadeamento e da ordenação das imagens. Não se fez um encaixe seletivo das imagens, dos presentes sucessivos, pois nesse procedimento os problemas colocados pela pesquisa não encontrariam solução. “A simples sucessão afeta os presentes que passam, mas cada presente coexiste com um passado e um futuro sem os quais ele próprio não passaria” (Deleuze,1990, p. 52). Também não se buscou uma causalidade, uma linearidade, uma evolução. Pretendeu-se que cada imagem tomada como presente, trouxesse nos acontecimentos uma variação da tensão entre o excesso e a escassez de água, evitando a simples polarização, e que as demais se distribuíssem em relação a ela como passado ou futuro, constituindo-se aí um feixe de relações passível de múltiplas variações.

O resultado obtido a cada montagem foi sofrendo várias edições, após avaliações e discussões entre a própria equipe e o consultor de vídeo e fotografia contratado. Na primeira edição de todo o material obteve-se uma seqüência de quatro horas e dez minutos de duração. Após ser discutida e analisada pela equipe, essa seqüência foi submetida a uma reedição para reduzir a sua duração, realizando-se cortes, que tiveram nas questões da pesquisa e na qualidade de imagem e áudio, os critérios para sua operacionalização. Ao final chegou-se a uma nova seqüência de duas horas e quatro minutos, que foi novamente submetida à discussão da equipe e concluiu-se por uma nova edição, a qual teria por objetivo chegar à duração de noventa minutos. Essa duração foi proposta pelo consultor contratado com o argumento de que as imagens e o áudio, por não terem sido feitas por profissionais, apresentavam problemas de qualidade técnica e estética, e mesmo após seleção e edição, poderiam comprometer a concentração do público no filme, além disso havia o propósito de exibi-lo a um público, que não está acostumado a esse formato de áudiovisual, e uma longa duração correria o risco de excluí-lo. Após um longo e exaustivo trabalho chegou-se ao resultado de noventa e três minutos, no qual foram ainda operadas algumas mudanças na montagem de modo a produzir-se melhores efeitos estéticos, que tiveram sempre por diretriz as questões colocadas pela pesquisa. Em decorrência de dificuldades de ordens técnica e profissional esse trabalho só pode ser concluído em abril de 2008.

A primeira exibição do documentário foi feita para as comunidades envolvidas na sua realização e contou com a participação de crianças, jovens, adultos e velhos. Ao longo da exibição houve manifestações de identificação, posicionamento, crítica a determinadas falas, emoções com risos e choros (duas das personagens morreram depois de concluídas as filmagens) , enfim, de uma participação efetiva das comunidades como público privilegiado, que ao mesmo tempo aprecia e julga o resultado do documentário do qual foi a personagem central. É interessante assinalar que essas manifestações também ocorreram em diferentes graus quando foi feita a exibição à comunidade acadêmica local, que discutiu a pesquisa implicando-se nela.

Diferentemente de quando apresentamos a pesquisa através de um relato escrito, o audiovisual possibilitou uma ampliação da discussão não só entre a comunidade acadêmica, bem como entre os pesquisados, que interferiram no processo de pesquisa bem como se posicionaram sobre o resultado final apresentado.

\section{Considerações finais}

Ao propor desenvolver nosso estudo em uma linguagem audiovisual, pretendíamos dar um outro tratamento às questões que determinaram a pesquisa que realizáramos anteriormente com as comunidades rurais de Massaroca, Juazeiro, Bahia. No audiovisual a pesquisa adquiriu uma outra perspectiva, na qual os membros das comunidades rurais foram tomados como intercessores, como personagens reais colocadas na condição de ficcionar por si próprias, de criar lendas. Essas comunidades rurais têm sido alvo ao longo dos últimos trinta anos de diversos projetos que pretendem levar-lhes o chamado "desenvolvimento" e, com regularidade, ignoram, destroem ou menosprezam os seus modos de existência. Há uma grande mudança em curso nesses modos de existência e a psicologia não pode ignorar os efeitos produzidos nos processos de subjetivação e o seu mapeamento permite dar visibilidade e dizibilidade aos problemas aí determinados.

A linguagem audiovisual favoreceu esta pesquisa no sentido de criar um campo experimental no qual os processos de subjetivação, não centrados em agentes individuais e nem grupais, pudessem ser mapeados no agenciamento de alguns sistemas nos quais as subjetividades estariam a se determinar. Tratamos de trazer em imagens e sons fragmentos de territórios existenciais das comunidades rurais, nos quais a tensão existente entre o excesso e a escassez de água é processada, parcialmente, em linguagem; práticas produtivas, econômicas, políticas e éticas; manifestações culturais; religiosidade; afetividade; modos de cognição e percepção. As estratégias criadas para lidar com essa tensão mudam assim como ela não é a mesma ao longo do 
ano e nem se repete do mesmo modo a cada ano.

Nesse sentido buscamos não limitar os processos de subjetivação a um significante teórico, que os reduzisse à produção de identidades estereotipadas (catingueiro, matuto, sertanejo, etc.), tal como é recursivo em diversos estudos acerca de populações que vivem em áreas como essa estudada. Entendemos que essas populações desenvolvem modos de existência nos quais processos de subjetivação se singularizam, os quais não se reduzem a estratégias de sobrevivência.

Ao discutirmos a ficção no documentário, buscamos liberá-la do modelo de verdade nela presente e trazer a simples função de fabulação, na qual pudemos pensar a participação dos membros das comunidades, não como expressão da identidade de uma personagem real, mas sim em seu devir. A equipe de pesquisa, de sua parte, pelas questões decorrentes do método experimental adotado, enfrentava as situações flagradas no instante mesmo da filmagem e tinha na produção/criação do documentário a matéria mesma a ser subjetivada.

A pesquisa apresentada em linguagem audiovisual possibilitou compartilhá-la e discuti-la com um público bastante heterogêneo, tanto em termos de faixa etária, nível de escolaridade como de atividades profissionais. Há uma participação efetiva do público nas exibições, que se manifesta de modo crítico ao discutir as questões da pesquisa trabalhadas no documentário.

Algumas das questões colocadas pelo documentário como um outro campo experimental para o estudo dos processos de subjetivação são pertinentes também para pensar outras concepções de pesquisa, que não se apresentam através da linguagem audiovisual. Esperamos ao trazê-las problematizar a pesquisa nessa experimentação e fortalecer o campo de investigação na psicologia.

\section{Referências}

Avellar, J. C. (1996). Cinema e espectador. In I. Xavier (Org.), O cinema no século (pp. 217-243). Rio de Janeiro: Imago.

Bergson, H. (1992). L'effort intellectuel. In - L'énergie spirituelle. Paris: Presses Universitaries de France. Publicado originalmente na Revue Philosophique, jan. 1902. (Tradução de Rodrigo Ribeiro Alves Neto e Ericson Medronho; revisão de Amândio Gomes)

Bernardet, J. C., \& Xavier, I. (2003). Debate com mediação do professor Carlos Augusto Calil, diretor do Centro Cultural São Paulo, sobre o Documentário brasileiro contemporâneo [online, 15 de agosto 2003]. Obtido em 23 de outubro de 2003, de www.contracampo.he.com.br/53/ismailbernardet.htm. Catani, A. M. (1990). A aventura industrial e o cinema paulista. In F. Ramos (Org.) História do cinema brasileiro (pp. 191). São Paulo: Arte.

Da-Rim, S. (2004). Espelho partido. Rio de Janeiro: Azougue.

Deleuze, G. (1990). A imagem tempo: cinema 2 (E. A. Ribeiro, Trad.). São Paulo: Brasiliense.

Deleuze, G., \& Guattari, F. (1992). O que éfilosofia? (B. Prado Jr. \& A. A. Muñoz, Trad.). Rio de Janeiro: Ed. 34.

Duarte, R. (2002). Cinema \& Educação. Belo Horizonte: Autêntica.

Feldeman-Bianco, B., \& Leite, M. L. M. (1998). Desafios da imagem: fotografia, iconografia e vídeo nas ciências sociais. Campinas, São Paulo: Papirus.

Foucault, M. (1982). Microfísica do poder (R. Machado, Trad. e Org.). Rio de Janeiro: Graal.

Gardinier, R. (2007). O que há para saber sobre Ozualdo Candeias? Obtido em 13 de fevereiro de 2007, de www.contracampo.com.br/25/artigos.htm.

Guattari. F. (1984). O divã do pobre. In Psicanálise e cinema (pp. 13-23; C. Leite e M. Castro, Trad.). [coletânea do número 23 da Revista Communications]. Lisboa: Relógio D’Água.

Guattari, F., \& Rolnik, S. (1986). Micropolitica: cartografias do desejo. Rio de Janeiro: Vozes.

Lévy, P. (1996). O que é o virtual? (P. Neves, Trad.). São Paulo: Ed. 34.

Lins, C. (2004). O documentário de Eduardo Coutinho: televisão, cinema e vídeo. Rio de Janeiro: Zahar.

Luz, R. (2002). Filme e subjetividade. Rio de Janeiro: Contra Capa.

Peixoto, C. E. (1998). Caleidoscópio de imagens: uso do vídeo e a sua contribuição à análise das relações sociais. In B. Feldeman-Bianco \& M. L. M. Leite (Orgs.), Desafios da imagem: fotografia, iconografia e vídeo nas ciências sociais (pp. 213-224). Campinas, São Paulo: Papirus.

Ramos, F. P. (1996). Cinema e realidade: alguns aspectos estruturais da imagemcâmera e sua particular intensidade. In I. Xavier (Org.), O cinema no século (pp.14-160). Rio de Janeiro: Imago.

Rolnik, S. (1998) Principio antropofágico de individuação. Aula não-publicada, proferida em 01/04/1998, no Núcleo de Estudos e Pesquisas da Subjetividade, Programa de Psicologia Clinica, Pontifícia Universidade Católica de São Paulo.

Samain, E. (1998). Questões heurísticas em torno do uso das imagens em ciências sociais. In B. Feldeman-Bianco \& M. L. M. Leite (Orgs.), Desafios da imagem: fotografia, iconografia e video nas ciências sociais (pp.51-62). Campinas, São Paulo: Papirus.

Senra, S. (1996). Cinema e jornalismo. In I. Xavier (Org.), O cinema no século (pp. 87-105). Rio de Janeiro: Imago.

Teixeira, F. E. (2004). Introdução: cultura audiovisual e polifonia documental. In F. E. Teixeira (Org.), Documentário no Brasil: tradição e transformação (pp. 7-26). São Paulo: Summus.

Yakhini, S. (2004). O eu e o outro no filme documentário: uma possibilidade de encontro. Universidade Estadual de Campinas, Instituto de Artes. Obtido em 02 de março de 2004, de http://bocc.ubi.pt/pag/yakhni-sarah-eu-outrodocumentario.html. 
1. Nove comunidades rurais: Lagoinha, Curral Novo, Lagoa do Meio, Cachoeirinha, Caldeirão do Tibério, Cipó, Lagoa do Angico, Juá e Canoa, localizadas no distrito de Massaroca, a 60 km de Juazeiro, BA.

2. Divisão do roteiro em planos numerados, com indicações dramáticas e técnicas necessárias à filmagem ou à gravação das cenas. Acesso em 26/03/2004. Disponível em: http://www.orientfilmes.com.br/cinedicionario.asp.

3. Aparelho analógico para captação do som, que necessita de uma fita magnética de rolo. Este gravador é bastante conhecido pelo nome de seu fabricante, Nagra, da Suíça. Acesso em 15/05/2007. Disponível em http://www.fflch. usp.br/cedoch/textos/A_hist_ria_do_acervo_hist_rico_do_Laborat_orio.doc.

Giovanna De Marco, doutora em Psicologia Clínica pela Pontifícia Universidade Católica de São Paulo, é professora titular no Departamento de Ciências Humanas da Universidade do Estado da Bahia, Campus III, Juazeiro. Endereço para correspondência: Rua Cesário da Silva, 77, Centro; Juazeiro, BA; CEP 48905-070. Tel. (74) 3611-6860. E-mail: giovannamarco@yahoo.com.br Ana Lorena Oliveira de Andrade é pedagoga, com habilitação em Educação Infantil e Magistério do Ensino Fundamental nas Séries Iniciais pela Universidade do Estado da Bahia e ex-bolsista de iniciação cientifica. E-mail: aninha_lore@yahoo.com.br

Cíntia Sacramento do Espírito Santo é aluna egressa do curso de Comunicação Social, Jornalismo em Multimeios, pela Universidade do Estado da Bahia e ex-bolsista de iniciação científica. E-mail: cintiacsj@ hotmail.com 